\title{
A Retrospective LoOK at OUR EVOLVING UndERSTANDING OF PROJECT SUCCESS
}

\section{[ABSTRACT]}

Our views on project success have changed over the years from definitions that were limited to the implementation phase of the project life cycle to definitions that reflect an appreciation of success over the entire project and product life cycle. This paper assesses our evolving understanding of project success over the past 40 years and discusses conditions for success, critical success factors and success frameworks. The paper concludes with a holistic view of project success and its implications for practice. This is an important topic because projects are an increasingly common way of work, and the lines between project and process work are harder to discern. Increasingly, more project managers work in companies using program and portfolio management as a means to organize projectrelated work. The success of individual projects, therefore, impacts the wider organization in several dimensions and makes the concept of project and project management success that much more relevant. The topic is also important because it has a bearing on the future directions of project management in the strategic context.

Keywords: project management; critical success factors; project life cycle; product life cycle; project success; program and portfolio management

Q2005 by the Project Management Institute Vol. 36, No. 4, 19-31, ISSN 8756-9728/03
KAM JUGDEV, Assistant Professor, Project Management and Strategy Centre for Innovative Management, Athabasca University Calgary, Alberta, Canada

RALF MOLLER, Assistant Professor, Department of Business Administration School of Business and Economics, Umeå University, Umeå, Sweden

\section{Introduction}

uccess is an interesting word. The word connotes different things to different people and is very context-dependent. Trying to pin down what success means in the project context is akin to gaining consensus from a group of people on the definition of "good art."

The purpose of this paper is to present a retrospective look at project success in the literature over the past $\mathbf{4 0}$ years and provide an outlook on the understanding of project success in the near future. Our views on project success have changed over the years from definitions that were limited to the implementation phase of the project life cycle to definitions that reflect an appreciation of success over the project and product life cycle. Project management can have strategic value when a clear connection is made between how efficiently and effectively a project is done and how the project's products and services provide business value. However, if project success is limited to the variables of time, cost, and scope-and the links to product/service value are missing-then project management is perceived as providing tactical (operational) value and not strategic value.

The discussion is relevant to academics studying the concepts of success and failure, as it presents a synthesis of the literature. The topic is important because it has bearings on the future directions of project management in the strategic context and in view of some areas of current research in the field (e.g., program and portfolio management, maturity models, and strategic project management).

The topic raises important issues for consideration regarding project success and client expectations management. A diversified understanding of success is necessary for both project managers and executives. Practitioners often manage multiple projects and face competing priorities on a daily basis, particularly as they simultaneously manage several projects at various stages of their life cycles and strive to balance diverse objectives stemming from various stakeholder agendas. Project managers must answer the question "How is your project doing?" To do that, they are constantly trying to define and manage project success in both subjective and objective ways. A basic understanding of the concepts and issues related to success is therefore essential for project managers. To that end, the paper finishes with practical advice for project managers on trends and future interpretations of project success. 
These days, project managers and executives are also increasingly involved in projects as part of a program or portfolio of projects (i.e., an organization that companies use to manage projects within and between departments). These practices enable companies to better integrate projects within the permanent organizational structure. As projects become an increasingly common way of work, the lines between projects and process work are becoming harder to discern. As more people work in an environment where program and portfolio management practices are used, they need to understand how project success is defined, particularly in terms of the project and product life cycles, because program and portfolio success is an aggregate of project success.

The paper begins with a look at asset valuation and strategic and operational assets. Then, the paper examines project success across the project and product life cycles. This is followed by a review of the four periods in the project management literature and a discussion on conditions for project success, project critical success factors (CSF), and project success frameworks. The paper concludes with a holistic view of project management success and a discussion on implications for practice. We begin with an overview of asset valuation.

\section{Product/Service Value}

Company success is widely defined as winning in the marketplace, and firms tend to measure this with financial and economic indicators (i.e., return measures, market share measures, and stock value measures [Barney, 1996]). Companies focus on their asset mix and determine which ones they should develop further and which ones to deemphasize. As a society, we are accustomed to the financial model that looks at tangible assets and values them in dollars, but "...the essence of wealth is the prospect of benefits, not their physical source" (Baxter, 1985, p. 218). In other words, the emphasis is on qualitative measures. Two examples of qualitative measures in the management literature include the Balanced
Score Card and Intangible Asset Monitor (Sveiby, 1997). Financial performance measures remain the mainstay in practice though, as there is no consensus on how to measure intangible assets (Allee, 2001).

In the race to create business value, companies are turning to project management to help them move beyond positions of competitive disadvantage or parity. Early mechanistic definitions of project management focused on the variables of time, cost, and scope-otherwise known as the "iron triangle" (Atkinson, 1999). Recent definitions of project management are more inclusive and emphasize the importance of working with stakeholders to define needs, expectations, and project tasks. These definitions describe project management as involving cultural, structural, practical, and interpersonal aspects (Cleland \& Ireland, 2002). "Project management is about managing people to deliver results, not managing work" (Turner, 1999, p. 4). Project management, then, is applied on projects to optimize efficiency and effectiveness. However, the emphasis in the literature has been on project management's value to optimize efficiency, and this entrenches it as an operational concept.

Efficiency looks at maximizing output for a given level of input, and effectiveness means achieving the goals or objectives; both are goal-oriented practices related to achieving success (Belout, 1998). Colloquially, efficiency is widely known as doing things right, and effectiveness as doing the right things. The Project Management Institute's (PMI's) globally established A Guide to the Project Management Body of Knowledge (PMBOK ${ }^{\circledR}$ Guide) does not define these terms, but refers to such efficiency indicators as schedule and cost efficiency ratios (Project Management Institute, 2004a). Literature on the advantages of using project management widely emphasizes efficiency indicators, such as increasing profitability and reducing costs, cycle time, and risks of failure (Kerzner, 1994). Literature on the tradeoffs between time, cost, and scope (including quali- ty) indicates that scope is the primary determinant of project success (Tukel \& Rom, 2001).

Quality improvement tools and techniques in project management help draw attention towards effectiveness measures and heighten awareness of the importance of gathering input from the customer (Jonker, 2000; Kumar \& Wolf, 1992; McManus, 1999). However, effectiveness measures are not tangible or as easy to grasp as efficiency metrics, and they take longer to determine (e.g., over the course of the process improvement or project life cycle). Effectiveness, then, became a secondary area of focus in project management (Belout, 1998). The focus on efficiency measures further establishes project management as an operational asset-we have much work to do before project management is viewed of and supported as a strategic asset.

\section{Strategic and Operational Assets}

At the strategic level of the firm, executives focus on creating the company's strategy, vision, and mission. These concepts are then put into practice at the operational level of the firm by those who implement the plans and create the related products and services (Floyd \& Woolridge, 1997). Middle managers are instrumental in implementing the firm's strategy, whereby producing products and services often involves project management practices.

Companies focus on those assets that, when developed and sustained, provide them with a competitive advantage (Barney, 2002). Other less important assets are viewed as support assets, and are typically done at the operational level. Some of the literature purports to discuss project management strategically but actually focuses on it as an operational concept (ESI-International, 2001; Hartman, 2000; Ibbs \& Kwak, 1997; Pennypacker, 2001). In particular, the work on project management maturity models purports to provide companies with a competitive advantage. A recent critique of these models indicates that this is not the case and that an investment in project management maturity 
practices, for the most part, lead to competitive parity (Jugdev \& Thomas, 2002a). Project management maturity models assess codified competences at the project and program levels (Kujala \& Artto, 2000; Lubianiker \& Schwartz, 2001). Many of the models consist of five linear stages: initial, repeatable, defined, managed, and optimized (Dinsmore, 1998). The maturity models focus on incremental improvements at the project and operational level and emphasize knowledge that can be transferred through documents, surveys, guidelines, templates, or manuals. However, value creation involves more than explicit knowledge capture. Value creation involves combining tangible assets such as financial, physical, and technological assets with less tangible ones such as human, organizational, and social assets (Brush, Greene, Hart, \& Haller, 2001). The Valuable, Rare, Inimitable, and Organizational Focus (VRIO) framework asks if the resource is valuable, rare, inimitable, and organizationally focused (Barney, 2001). Upon assessing project management maturity models against these criteria, we found that the models are not, in and of themselves, a source of competitive advantage as claimed (Jugdev \& Thomas, 2002b). One reason is that maturity models address codified (tangible) knowledge, and a large part of project management knowledge is intangible and knowledge-based. The intangible knowledge resides in a firm's organizational, human, and social capital.

Kloppenborg and Opfer's (2002) meta-analysis of the project management literature (of primarily North American publications) supports the stance that project management is a tactical concept. In the 1970s, the literature focused on tools and techniques (i.e., software, work breakdown structures, and program evaluation and review techniques). In the 1980 s, the literature began to focus on the importance of the "profession" but remained technically oriented as it covered design-to-cost, life cycle costing, risk management, cost and schedule control, and control systems. However, the literature also started to address such topics as team building and quality. In the 1990s, the literature took more of a human resources approach and dealt with leadership topics. More recent project management literature focuses on competences, stakeholders, performance measures, and project management as a career path. For the most part, though, the meta analysis indicates that publications in project management primarily focused on tools and techniques and the practice at the tactical level of the firm. Further support for this position was evident in the Ulri and Ulri (2000) scientometric analysis of 3,565 articles (primarily North American) that identified evolutionary trends and themes in project management from 1987-1996). Their findings indicate that before the 1992 1997 period, few publications discussed project management in the context of strategic planning, company mission, and the importance of corporate management performance.

Cabanis describes the connection between project management and strategy by stating that the connection is about involving the project manager at the start of the project (e.g., project selection and/or the sales process [Cabanis, 1998]). However, this is an operational definition because, in practical terms, strategic management is about "the direction of organizations" and deals with firm success, failure, and competition (Rumelt, Schendel, \& Teece, 1994, p. 9). In contrast, Toney (1997) indicates that project management could achieve a "strategic position" by addressing several problem areas: promoting project management benefits, measuring the results of project management, and addressing both personnel and methodology issues. These topics are a blend of what needs to be addressed at the tactical level and strategic levels of the firm. In particular, measuring the results of project management connotes how project management could support long-term organizational success.

If business value is about efficiency and effectiveness, how has the literature on success contributed to our understanding of project management as an organizational asset? To answer this question, we take the perspective of the project and product life cycles and then review chronologically the development of project success.

\section{The Project and Product Life Cycles}

In this section, we present an overview of the project and product life cycles to explain how our views on project success were narrowly defined over the years. This restricted outlook contributes to our understanding of project management as an operational concept rather than one with clear strategic value. The project life cycle is:

"A collection of generally sequential project phases whose name and number are determined by the control needs of the organization or organizations involved in the project" (Project Management Institute, 2000, p. 192).

The $P M B O K^{\circledR}$ Guide describes the project life cycle as a subset of the product life cycle, with the product life cycle typically including an operational phase followed by decommissioning or retirement (Project Management Institute, 2004a). The $P M B O K^{\circledR}$ Guide cautions that "care should be taken to distinguish the project life cycle from the product life cycle" (Project Management Institute, 2004a, p. 24) (emphasis added).

The $P M B O K^{\otimes}$ Guide presents several representations of the project life cycle that link the project to the firm's operations (Project Management Institute, 2004a). Most project life cycles include phases of conceptualization, planning, execution, and termination (Pinto \& Prescott, 1990). Turner (1999) uses the terms germination (proposal and initiation), growth (design and appraisal), maturity (execution and control), and metamorphosis (finalization and closeout). They do not typically address phases beyond termination, such as the product/service use phases. The following table portrays examples of project and product life cycles from the $P M B O{ }^{\otimes}$ Guide. 


\begin{tabular}{|c|c|c|c|c|c|c|}
\hline \multicolumn{3}{|c|}{ PHASES } & CONSTRUCTION & PHARMACEUTICAL & $\begin{array}{c}\text { DEFENSE } \\
\text { AGQUISITION }\end{array}$ & $\begin{array}{c}\text { SOFTWARE } \\
\text { DEVELOPMENT }\end{array}$ \\
\hline \multirow{5}{*}{ 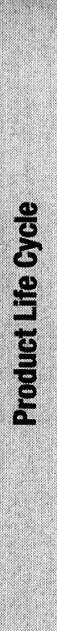 } & $\begin{array}{l}\text { Initial Phase: } \\
\text { Conceptualization, } \\
\text { Planning }\end{array}$ & \multirow{4}{*}{ 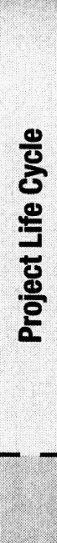 } & Feasibility & Discovery \& Screening & $\begin{array}{l}\text { Concept Exploration \& } \\
\text { Definition }\end{array}$ & Proof of Concept Cycle \\
\hline & \multirow{2}{*}{$\begin{array}{l}\text { Intermediate Phase: } \\
\text { Production / } \\
\text { Implementation }\end{array}$} & & Planning and Design & $\begin{array}{l}\text { Pre-Clinical } \\
\text { Development }\end{array}$ & $\begin{array}{l}\text { Demonstration \& } \\
\text { Validation }\end{array}$ & First Build Cycle \\
\hline & & & Production & Registration(s) Workup & $\begin{array}{l}\text { Engineering \& } \\
\text { Manufacturing } \\
\text { Development }\end{array}$ & Second Build Cycle \\
\hline & $\begin{array}{l}\text { Final Phase: } \\
\text { Handover } \\
\text { Operations: } \\
\text { Utilization }\end{array}$ & & Turnover and Start Up & $\begin{array}{l}\text { Post-Submission } \\
\text { Activity }\end{array}$ & 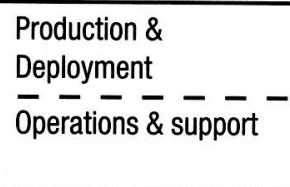 & $\begin{array}{l}\text { Final Cycle Including } \\
\text { Testing, Final Build } \\
\text { Deployment }\end{array}$ \\
\hline & $\begin{array}{l}\text { Decommissioning: } \\
\text { Closedown }\end{array}$ & & & & & \\
\hline
\end{tabular}

Table 1: Overview of the project and product life cycles (PMBOK ${ }^{\circledR}$ Guide)

In the above table, the term product life cycle refers to the initial, intermediate, and final project phases and the operations and decommission phases, whereas the term project life cycle describes the initial, intermediate, and final project phases (Project Management Institute, 2000). The horizontal hatched line portrays where the project life cycle ends within the product life cycle. The project life cycle, then, is a subset of the product life cycle. The table also shows four different project life cycles spanning the construction, pharmaceutical, defense acquisition, and software development industries. The grey shading in the lower half of the table shows the phases that are not covered by the industryspecific project life cycles. For the purposes of this paper, we are discussing both the project process (that spans the project life cycle) as well as the product (that spans the product life cycle phases) (Wateridge, 1998).

The above table also reflects variation in terminology as well as some commonalities among the project types. Some of the terms used are industry-specific (Project Management Institute, 2000). Although the $P M B O K^{\circledR}$ Guide indicates that different terms are used to describe project phases, it does not address these inconsistencies or the lack of standardization in the literature (Project Management Institute, 2004a). For example, the initial project phase is called feasibility, discovery and screening, concept exploration and definition, and proof of concept cycle across the four industry-specific project types above.

Project success is often erroneously assessed only at the end of the project life cycle, as project management outcomes are available and convenient to measure (Munns \& Bjeirmi, 1996). For example, the construction and pharmaceutical project life cycles end at the final project phase and do not span the product operations or decommissioning phases. In contrast, the defense acquisition and software development project life cycles include the operations phase and, hence, portray a clearer connection to product use and business value. We can achieve a more holistic understanding of project success by measuring success during operations and decommissioning when effectiveness measures are taken into account and involve input from different stakeholders (e.g., end users) (Atkinson, 1999; Freeman \& Beale, 1992; Munns \& Bjeirmi, 1996).

De Wit (1988) discusses the concept of project management success in terms of time, cost, and quality/performance (scope), and indicates that project success involves broader objectives from the viewpoints of stakeholders throughout the project life cycle. Although "good project management can contribute towards project success, it is unlikely to be able to prevent failure" (de Wit, 1988, p. 164). Another way of understanding this distinction is with the oft-heard saying that "the operation was a success, but the patient died." Therefore, Cooke-Davies (2002) distinguishes between:

- Project management success, being measured against the traditional gauges of performance (i.e., time, cost, and quality), and

- Project success, being measured against the overall objectives of the project.

One can no doubt think of examples where projects were not managed well from a project management perspective, yet were viewed as successful. For example, the Sydney Opera House took 15 years to build and was 14 times over budget, yet it is proudly displayed as an engineering masterpiece. So, in the de Wit and Cooke-Davies context, this initiative was a failure in terms of project management success, but it was a success in terms of project success (Baccarini, 1999; Munns \& Bjeirmi, 1996). Examples also abound whereby projects were managed well from a project management perspective, yet were perceived to be unsuccessful.

A 1998 study on measuring project success in the information technol- 
ogy industry noted the importance of considering stakeholder input on success and examining success in the context of the project's process and product (Wateridge, 1998). Life cycles that do not measure success beyond the final project phase limit the project manager's responsibilities regarding problems that arise during the production phase, and this can create customer satisfaction issues. Narrowly defined life cycles also detract from the project team working more cohesively with the business team and contribute to an attitude of "that's not my problem" (Frame, 1994, p. 6). Such issues perpetuate the focus on efficiency metrics, which are easier to calculate when compared to less tangible success factors. This approach also looks at project success from the narrow perspective of the project manager and team rather than the broader perspective of stakeholders, such as end users of the product or service. One reason for the emphasis on time, cost, and scope relates to project managers being appraised on their ability to deliver to these short-term criteria. "With the decision to achieve time and cost constraints, project managers do not put great emphasis on users being happy with the system" (Wateridge, 1998, p. 62). This was especially evident in the Wateridge study when the failed project criteria for success were compared to the successful project criteria between project managers and end users. Wateridge noted that on successful projects, there was greater agreement on success criteria between the project managers and end users than there was on unsuccessful projects. In addition, successful projects were more likely to emphasize product success (a longer-term objective), whereas unsuccessful projects involved an emphasis on time, cost, and scope.

The project-centric view on success entrenches project management's value at the tactical level of the firm. Tactical practices receive mid-management attention where strategy is implemented and operational improvements made (Floyd \& Woolridge, 1997). Tactical concepts rarely receive enduring senior manage-

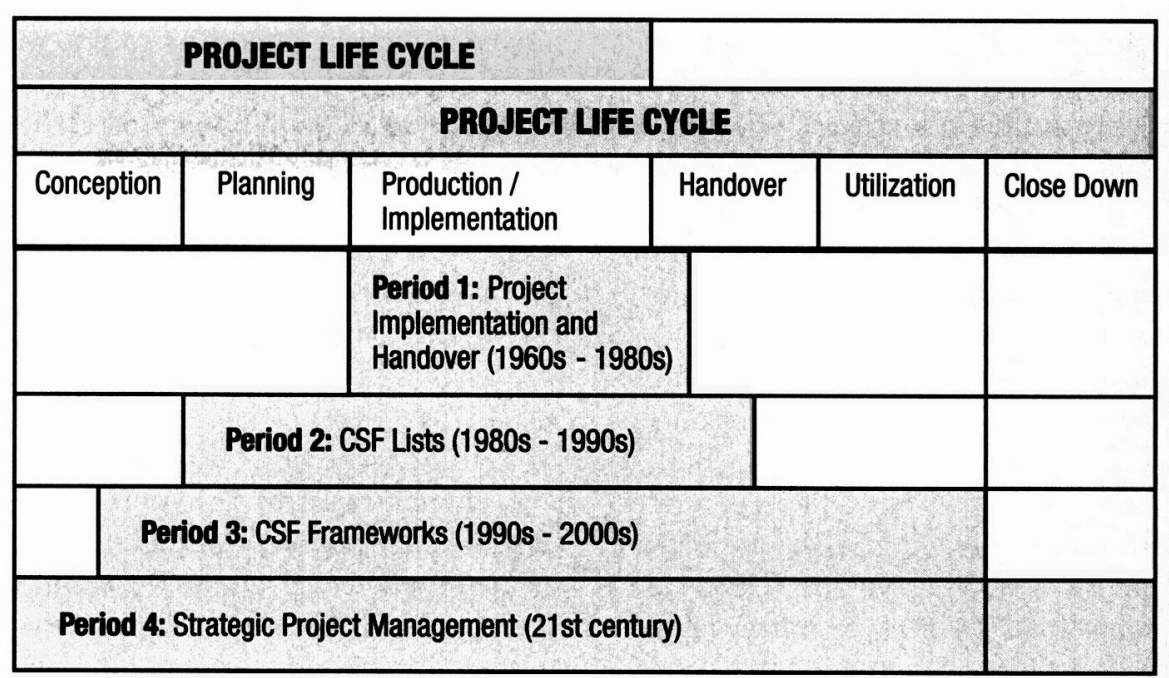

Table 2: Measuring success across the project and product life cycles

ment attention. Frame refers to these narrow outlooks as traditional project management practices, and urges project managers to broaden their span of responsibility and accountability (Frame, 1994). Our understanding of project management success is also influenced by work in the area of CSFs, success frameworks, and conditions for success. The next section presents a retrospective look at project success.

\section{A Retrospective Look at Project Management Success over the Years}

Our understanding of success as a broader, organizational concept is evolving. Initially, the literature was predominated by lists of project success criteria (e.g., a project is successful if attention is placed on a clear mission, there is senior management support, and scope is managed). This led to the development of CSFs and preliminary success frameworks, followed by more recent holistic frameworks on success. Mention of strategic management terms remained nominal over the past 40 years, and a direct link between operations management and strategic management was noticeably absent in the project management literature. Based on a literature review of approximately 30 articles, primarily from North American sources, Table 2 portrays trends regarding project management success. The framework involves three periods: Periods 1 and 2 focused primarily on the project life cycle. The product life cycle phases of utilization and closedown did not emerge as components of the project management success literature until Period 3, when more comprehensive CSF frameworks were developed.

As the next sections indicate, the past 40 years saw a slow but gradual understanding that project management success should be assessed with input from stakeholders, and it should be assessed beyond the project phases. Note that each subsequent period spans more project phases, and the success frameworks in Period 3 cover all the product life cycle phases. These periods are now reviewed in detail.

Period 1: Project Implementation and Handover (1960s-1980s)

Success is measured in subjective and objective ways and it means different things to different people (Freeman \& Beale, 1992). During Period 1, simple metrics such as time, cost, and specifications were used to rate project success because they are easy to use and within the realm of the project organization. Project managers focused on getting a project done, making sure it worked, and getting it out the door. Customer contact was minimal, along with long-term follow-up and troubleshooting. The early literature as well as practice predominantly supported the iron triangle as the foundation of project management (Atkinson, 1999; Cooke-Davies, 1990; Hartman, 2000).

In Period 1, the literature was the- 
oretical and extensive empirical work was lacking (Belassi \& Tukel, 1996). Early studies looked at why projects failed or succeeded by focusing on the schedule; other studies defined success in terms of achieving the goals of time, budget, and performance (Pinto \& Slevin, 1988b). The literature also focused on the implementation or execution phase where the attention was on these three variables (Lim \& Mohamed, 1999). This was understandable as the implementation phase was typically the longest and consumed the most resources (Project Management Institute, 2000). Also, important issues not addressed earlier came to a head during this phase. Project implementation is an efficiency-oriented phase and involves project management process criteria (Atkinson, 1999). Time and cost are best guesses, typically calculated when less is known during the planning phases, and quality is an attitude that changes over the project life cycle. Atkinson adds that there was a failure to take a bigger picture view of success in terms assessing it after delivery. Measuring success after delivery involves looking at the benefits or effectiveness of the project from the perspective of the stakeholder community and resultant organization.

Similar to the concept of project success, client satisfaction remains a nebulous and complex concept, and is often measured by surrogates (e.g., complaints or surveys) (Pinto \& Slevin, $1988 \mathrm{~b}$ ). The literature reflected a gradual trend towards including client satisfaction as a variable in assessing project success, both at the end of the project life cycle and into the product life cycle. This included an understanding of upfront measures such as defining needs at the onset, but also assumed that the parties knew how to define their needs (Shenhar, Levy, \& Dvir, 1997).

Historically, then, the research emphasized efficiency measures and the technical system instead of the behavioral or interpersonal systems, otherwise known as the "hard skills" vs. "soft skills" (Munns \& Bjeirmi, 1996). When the focus was on a mech- anistic approach, the objective was to reach target dates, a financial plan, and an end product. Well into Period 2, the iron triangle continued to be used to describe success in project management, with a narrow focus on the project management phases, especially the project implementation phase.

\section{Period 2: CSF Lists (1980s-1990s)}

In Period 2, the emphasis in project management was on developing CSF lists. Kerzner defined CSFs as the few elements where "things must go right" (Kerzner, 1987, p. 32). CSFs are the "elements required to create an environment where projects are managed consistently with excellence" (Kerzner, 1987, p. 32). The literature focused on the importance of stakeholder satisfaction as an indicator of project success. Once the project is complete, short-term memories fade and the focus shifts from completion criteria, "are we done?" to the satisfaction criterion, "are we happy?" "This is the acid test of the original concept of the project" (Lim \& Mohamed, 1999, p. 246). Users are generally more demanding with satisfaction criteria than completion criteria. "Satisfying end users' needs is one facet of quality assurance and...quality is defined as the satisfaction of users' needs" (Munns \& Bjeirmi, 1996, p. 83). Customer satisfaction is increasingly important because of the competitive marketplace and attention to service and satisfaction.

The following examples of requirements for successful projects/project management demonstrate the earlier focus on the execution phase as well as the list approach to CSFs, instead of a categorization scheme or framework. A successful project involves staff training and education, dedicated resources, good tools, strong leadership and management, and concurrent development of the individual, team, and organization (Bounds, 1998).

Historically, most project managers attended to CSFs in an intuitive manner. One review on prior studies categorized project success and noted that the factors listed could not explain why some viewed projects as successful but others did not. Lim and Mohamed (1999) also surveyed experienced project managers and found that people were split on the ambiguities of success. Success was a rarely agreed-to construct.

The literature to the mid-1980s listed success factors using anecdotes and single case studies (Pinto \& Prescott, 1990). Project success contributed to excellence within time, cost, and performance/quality levels (Kerzner, 1987). These metrics may be misleading if expectations are not met. Success was typically described with a single measure for the project instead of multiple measures over the life cycle (e.g., the project was either a success or it was a failure).

Lim \& Mohamed (1999) used the forest and trees analogy to describe the difference between the macro and micro viewpoints of the project. The micro viewpoint involved assessing project management success upon project completion, whereas the macro viewpoint involved the longer-range perspective of product use to measure customer satisfaction. The argument was that determining whether the original project concept was achieved could not be made until the operational stage. The operational stage occurred after the project had passed to the receiving organization and the project required input from the users and stakeholders. The work was significant because it referred to setting expectations at the project's onset. This approach contributed to alignment between project deliverables and expectations so that the work could be guided along those lines.

Clarke's project CSFs included effective communication, clear objectives and scope, dividing the project into manageable components, and using project plans as living documents (Clarke, 1999). She was critical of some of the project success literature due to the lack of advice on how to apply the success concepts practically.

To summarize Period 2, a number of useful CSFs were identified and described. However, these publications neither grouped nor integrated the concepts in a coherent manner. Few 
sources specifically mentioned organizational effectiveness, change management and, more importantly, alignment between project management and strategic management, although some of these concepts were alluded to. Transitioning from Period 2 to Period 3, we noticed the emergence of CSF frameworks.

\section{Period 3: CSF Frameworks \\ (1990s-2000s)}

In the 1990s, we saw some significant contributions to the literature with the emergence of integrated frameworks on project success. Most of the publications on the topic addressed the concept that success was stakeholder-dependent and that success involved the interactions between the internal and recipient organization (Kerzner, 1987; Lester, 1998).

Morris and Hough (1987) were pioneers in developing a comprehensive framework on the preconditions of project success. They analyzed project success in the context of major projects and the work was based on eight case studies. They grouped project success as follows:

- Project functionality: Does the project meet financial and technical requirements?

- Project management: Did the project meet the budget, schedule, and specifications?

- Contractors' commercial performance: Did the contractors benefit commercially?

- Project termination: In the event that the project had to be cancelled, was this decision made reasonably and efficiently?

Morris and Hough developed a comprehensive framework depicting the elements of project success. The elements included attitudes, project definition, external factors, finance, organization and contract strategy, schedule, communications and control, human qualities, and resources management. Their book addressed the concepts that success is both subjective and objective, that success varies across the project and product life cycle, and that various stakeholders are involved (Morris \& Hough, 1987). What was striking was that numerous other publications, particularly those in North America, did not build on this conceptual framework. Instead, most of the literature continued to develop CSF lists in this period and a few proposed CSF frameworks, but did not dovetail their work with the one by Morris and Hough.

Cleland and Ireland (2002) suggested that success be viewed from two vantage points-the degree to which technical project performance objectives were attained (e.g., time, cost, and scope) and the contribution that the project made to the strategic mission of the firm. Others took this one step further and included the customer organization as an additional concept (Belassi \& Tukel, 1996; Kerzner, 1987; Morris \& Hough, 1987; Turner, 1999).

Kerzner broadened the span of CSFs by stating that they applied to projects, project management, the project organization, senior management, and the environment (Kerzner, 1987). The paper also described the interfaces between the internal and external environment as the dynamic arenas in which companies sought success. Although Kerzner then went on to simply list the CSFs, the CSFs included a corporate understanding of project management by everyone involved, executive commitment to project management, organizational adaptability, project manager selection criteria, project manager leadership style, and a commitment to planning and control. Having a corporate understanding was seen to be the most important CSF as it related to managing and leading change initiatives.

Freeman and Beale (1992) also listed criteria for measuring success that were similar to Kerzner's. He identified the criteria for measuring success as including technical performance, efficiency of execution, managerial and organizational implications (customer satisfaction), personal growth, manufacturability, and business performance. Both the Kerzner, and Freeman and Beale, contributions identified categories of success, but lacked the depth of integrated frameworks observed more recently in the literature as discussed under Period 4 in the next section.

Pinto published a number of articles between 1987-1990 on CSFs and is widely known for the "10 CSF" list: project mission, top management support, project schedule/plan, client consultation, personnel, technology to support the project, client acceptance, monitoring and feedback, channels of communication, and troubleshooting expertise (Pinto \& Covin, 1989; Pinto \& Mantel, 1990; Pinto \& Prescott, 1990; Pinto \& Slevin, 1987, 1988a, 1989). Pinto grouped the CSFs into planning and tactical categories. Of the 10 CSFs, project mission, top management support, project schedule/plan and client consultation were placed in the planning category and the rest under tactical. However, the CSFs were still narrowly limited to the project life cycle itself. Success was interpreted as the project being done well and project management being applied appropriately to achieve that end. In other words, the focus was at the business operational level. Pinto's use of the term planning did not make a direct link to strategic management planning or align project management to the overall business directions of the firm.

Pinto developed a framework for implementation success wherein the three concentric circles of technical validity, organizational validity, and organizational effectiveness overlapped (Pinto \& Slevin, 1988b). Note that two out of the three success constructs were equally important to the project and client organization, namely organizational validity and organizational effectiveness. Prior to this, the dominant view was that project success was internally focused when, in fact, it had a strong external component in the customer's organization and the delivery organization had a responsibility to ensure the project worked after it was delivered.

Pinto also reported that CSFs were not of equal importance throughout the life cycle stages of conceptualization, planning, execution and termination; however, the project mission (initial clarity of goals and general 
directions) was important at all four phases of the project life cycle (Pinto \& Slevin, 1988a). Some CSFs were common to projects regardless of project type, others were specific to project groupings and the relative importance of CSFs varied over the course of the project life cycle (Pinto \& Covin, 1989). Furthermore, project success was multidimensional and perceived project success consisted of three conceptually and statistically distinct factors that were consistent with the quadruple constraints (Pinto \& Prescott, 1990). The three groupings were: a) budget and schedule, b) value (positive impact, merit, improved organizational effectiveness), and c) client satisfaction (in terms of product use, benefits to end users through increased efficiency or employee effectiveness).

Project failures are expensive and, increasingly, companies are trying to understand what it takes for a project to be successful. The body of literature on project success also encompasses project failures. Since 1994, the CHAOS Chronicles (as published by the Standish Group) have studied project success and failure, with a focus on Information Technology projects. In their recent CHAOS report, the Standish Group reported that $26 \%$ of Information Technology projects were successful (Standish Group, 2003). They indicate that the top success factors involve user involvement, executive management support, experienced project managers, clear business objectives, minimizing scope, agile requirements processes, standard software infrastructure, a formal methodology, reliable estimates, skilled staff, effective tools, and process improvement using software development capability maturity models. Interestingly, the CHAOS list of success factors is very similar to those developed by Pinto in this period.

In the SMART ${ }^{\otimes}$ framework of project management, success was rooted in projects that were strategically managed, aligned, regenerative and involve transitional management (Hartman, 2000). "Communication at the right level and with the right people is at the heart of successful project manage- ment" (Hartman, 2000, p. 28). In addition, "People...are the single most important part of successful projects" (p. 67). Hartman's list of CSFs was similar to Pinto's, but wider in scope, as it emphasized the environment (e.g., social, natural, political, and corporate). Success was defined as "one where the stakeholders are satisfied with the outcomes" (p. 369). These elements were noted by both Morris and Hough (1987) and by Turner (1999).

According to Munns and Bjeirmi (1996), success involves a combination of progress during the implementation phase, perceived values, and client satisfaction. Implementation success deals with the effectiveness of project management, the perceived values deal with the views of end users using the product, and client satisfaction refers to measuring success after closedown. Munns also supported having the project team involved in the utilization phase so that end-user requirements could be confirmed and troubleshooting provided, rather than the team exiting at handoff.

One empirical study was based on a multidimensional, multi-observational framework used to identify four universal dimensions of success: a) project efficiency, b) impact on customers, c) business and direct success, and d) preparing for the future (Shenhar et al., 1997). Shenhar determined that the expected project values should be identified at a project's onset so that everyone was aware of them during the project. The study identified three clusters of success: a) meeting design goals, b) impact on the customer, and c) benefits to the organization. Furthermore, project managers actually distinguish between four universal dimensions of success: a) project efficiency, b) impact on customers, c) business and direct success, and $\mathrm{d}$ ) strategic potential. Shenhar noted that meeting design goals (time, budget, and performance) was not a homogeneous dimension. Time and budget comprised one dimension, as it was resource-related, but meeting specifications related to customer satisfaction. This was a significant distinction, as others to date had grouped the three elements into the iron triangle of time, cost, and scope.

Success also varies with time over the course of the project and product life cycles (Shenhar et al., 1997). Project success is an integrative concept that includes short- and long-term implications, such as project efficiency, customers, business success, and preparing for the future. Efficiency is typically realized at project turnover to operations, whereas business success and future potential are longer-term dimensions that connote effectiveness measures. For example, profit and increased market share are immediate results of a well-run project, but there are also long-term advantages to be considered that relate to new markets, new products, and establishing longterm strength. Unlike earlier papers that prioritize time, cost, and scope as success criteria, Shenhar's study placed customer satisfaction as the numberone criterion for overall project success, and put the iron triangle second (Shenhar et al., 1997).

Of the CSF literature reviewed, Belassi and Tukel (1996) presented a holistic framework that included within-firm and industry factors. Their literature review found that most authors tabulated individual success factors, but did not group or classify them. The Belassi and Tukel classification enables readers to clearly see what category certain CSFs belong to, and the classification system allows for an examination of CSF interrelationships. The four categories are factors related to the project, factors related to the project manager and team, factors related to the organization, and factors related to the external environment.

The scheme is systematic and helps readers clearly see the relationships and implications when these factors are not addressed. The study shows that CSFs vary with industry and that top management support is vital. The scheme appears unique relative to other frameworks because it integrated project dimensions with organizational and environmental factors. To exemplify the integrative nature of the Belassi framework, Wateridge identified six CSFs in his framework that 
essentially fit Period 3: The project is profitable for the sponsor/owner and contractors; achieves its business purpose in three ways (tactically, operationally, and strategically); meets its defined objective; meets quality thresholds; is produced to specification, within budget, and on time; and all parties (users, sponsors, project team) are happy during the project and with the project outcomes (Wateridge, 1998). These CSFs can be grouped into Belassi's framework and, for the most part, are those that relate to the project, project manager and team, and organization. The factors seem to exclude the external environment.

An examination of some European publications suggested that the progress made in terms of the success literature in North America was not all that unique. One integrated model on the strategic management of projects suggests that projects are influenced by seven forces that help determine project success (Morris \& Hough, 1987). The model involves (i) the external context of the project that encompasses project sponsorship (including the budget and schedule), and (ii) external influences such as political, social, technical, legal, environmental, and economic factors. The project also involves a project strategy that consists of (iii) attitudes that reflect the importance attached to the project and support given to it at all levels of management and (iv) definition that indicates what the project will accomplish and the approach to design and technology to achieve this. In addition, the framework involves internal driving forces such as (v) people and their management, leadership, and teamwork, (vi) systems related to planning, reporting, and control, and (vii) organization related to roles, responsibilities, and contractual relationships.

Similarly, Turner (1999) builds on the framework by Morris and Hough in his 1999 handbook of project-based management and discusses how successful projects are judged using multiple subjective and objective criteria. Turner argues that a successful project should: a) meet its stated business purpose, b) provide satisfactory benefits to the owner, c) satisfy the needs of owners, users, and stakeholders, d) meet its prestated objectives to produce the facility, e) have a deliverable that should be produced to specification, within budget, and on time, f) satisfy the needs of the project team and supporters, and $g$ ) make a profit for them. Turner (1999, p. 72) notes that the measures are not necessarily compatible "so the judgment depends on a complex balance." Turner (1999) also provides a success/failure diagnostic in his book and it consists of 85 questions. Although not specified, it appears that this diagnostic is in keeping with his framework.

In many respects, the framework by Morris is very similar to the one by Belassi and Tukel (1996). Interestingly, the Belassi and Tukel paper is entitled "A new framework for determining critical success/failure factors in projects"; yet, in comparing this work to the ones by Turner (1999) and Morris and Hough (1987), it really is not new. It is regrettable that publications in Europe discussed success factors, success criteria, and success frameworks back in the late 1980s, yet some of the North American publications introduce these concepts almost a decade later as if they were new insights. Perhaps this is partly due to the emphasis in North America on peerreviewed journals-the works by Morris and Turner appeared in books.

Towards the end of this period, the Scandinavian project management literature started to define project success as being made up of the myriad of side effects that project work brings with and in itself. Sahlin (1996) showed that projects in municipalities, such as those against drug abuse, are often considered as being successful even if they do not meet predetermined objectives. These objectives are set prior to project start in order to obtain funding. During project execution, however, a learning process is initiated, and this process helps to define project outcomes. The learning, and the sideeffects through interaction with other institutions and organizations, outweigh the originally planned project objectives and lead to synergies not achievable by doing projects in isolation (Sahlin, 1996). Along similar lines, Engwall (2002) suggests the use of ambiguous objectives to allow learning during project execution and flexibility in adapting project deliverables to changes in the project's context (e.g., in the project marketplace).

Generally, conceptual papers precede empirical studies, as conceptual papers enable researchers to further develop concepts and discuss how they might operationalize concepts as constructs to be measured. As this paper has indicated, considerable work has occurred on conceptualizing success in the project and project management contexts.

Success, then, evolved from the project being merely technically correct in the views of the providing organization to how the project interfaced with the client organization and flowed from internal and external factors (Pinto \& Slevin, 1988b). However, efforts to monitor and anticipate project outcomes were hampered as agreed to determinations of success did not exist (Pinto \& Slevin, 1988b). Wenell (2000) showed that this is based in the different perspectives towards project objectives. While project managers work toward project objectives defined for their specific projects, line managers see projects as building blocks to achieve an overall business objective ("effect-goal") that arises from the productive use of the project outcomes. While it is desirable that project managers take responsibility for this wider objective, it is often not possible due to the temporary nature of the project team and the time gap between project delivery and accrual of business results. Similarly, Simons and Lucarelli (1998) suggested distinguishing between primary and secondary objectives of a project when it comes to assessing project success. Managerial implications were that project managers were rewarded through bonuses, promotions, and raises for their ability to manage projects successfully, but these criteria were often different from those that project managers used on the project. As a result, common performance criteria between managers 
and project managers are warranted (Pinto \& Prescott, 1990).

Period 4: Strategic Project Management (21st Century)

It is clear that we have made progress over the past 40 years on the topic of project and project management success:

- We understand that project success is more than having a common mission, top management support for resources, authority, and power to succeed on the project.

- We now understand that CSFs include senior management commitment to provide the vision, strategy, and sponsorship.

- We are aware that success factors relate to the organization (e.g., top management support) and to the external environment (e.g., politics, economy, social, technological, nature, client, competition, and subcontractors).

- We know that senior management within the project-initiating organization is ultimately responsible for ensuring the link between organizational plans and the goal and purpose of selected projects and the creative processes in identifying possible ideas for a project. Successful project management requires planning and a commitment to complete the project (that is, commitment from executives throughout - not just at the start).

In addition, we understand that project success dimensions include benefits to the organization and preparing for the future (e.g., innovating, and developing core competencies).

Most recent literature on project success summarizes the empirical results of several studies and outlines four necessary, but not sufficient, conditions for project success. All of them need to be in place for projects to be successful, but do not guarantee project success alone. These four conditions build on the work of Wateridge (1998) and Müller (2003), and are mentioned by Turner (2004, p. 350) as:

1. Success criteria should be agreed on with the stakeholders before the start of the project, and repeatedly at configuration review points throughout the project

2. A collaborative working relationship should be maintained between the project owner (or sponsor) and project manager, with both viewing the project as a partnership

3. The project manager should be empowered with flexibility to deal with unforeseen circumstances as they see best, and with the owner giving guidance as to how they think the project should be best achieved

4. The owner should take an interest in the performance of the project.

This approach shifts considerable responsibility for project success to the project owner. It reconfirms the need for the owner to empower the project manager and be willing to renegotiate success criteria over the project life cycle. However, it opens a new perspective that addresses the owner's underlying attitude and interest towards the project. Research by Müller (2003) showed that in successful projects the owner had an interest and willingness for continuous communication with the project manager, driven by an assumption that the project is performing under its capabilities. Owners in unsuccessful projects were significantly less interested in the project. The psychological predisposition of the project owner towards the project appears to be a new CSF, warranting further study.

It is the owner's task to implement an organization's strategy through projects: However, if project management is not seen as a strategic asset in an organization, then the owners show lower interest toward the management of their projects. This attitude, as mentioned above, is associated with unsuccessful projects. An organization's understanding of project management as a strategic asset, therefore, becomes a key criterion for project success.

A continued emphasis on project management success at the organizational level will help shift attention to effectiveness metrics and reflect a more holistic view on the value of project management as a core or strategic asset. Further progress in this regard will help us move project management from an organization's tactical level to the strategic level.

This paper indicates our gradual progress over the years towards a comprehensive view of success. Although a few authors presented project management success in a holistic manner, linking it to organizational success, most citations discussed project success narrowly within the context of the project life cycle. This is in line with the Ulri and Ulri (2000) finding that the strategic management literature on project management emerged after 1992.

We said in the beginning that projects are increasingly used as a way to organize work towards achievement of organizational objectives. The simultaneous pressure on firms to achieve economic objectives through projects forces them to view success as a combination of both project and project management success (i.e., a success both in the short-term as well as in the long-term). Both forms of success are inextricably interlinked and determine whether or not organizations achieve their objectives. Examples include projects as parts of programs, where the entire program is dependent on the success of each individual project, caused by mutual dependency of project outcomes. Other examples include project portfolios, where the project management success of economic resource usage in each project impacts an organization's overall results.

This turning point marked the end of the era where project managers could deliver whatever was contracted without caring about the acceptance and usability of the project deliverables. Turner and Müller (2004) suggest that project managers should be measured on a wider set of objectives, not just the achievement of time, cost, and functionality goals. Similar to the CEO of a company, project managers should be measured and remunerated on a balanced contribution towards the success of the project and the entire organization. This includes the manage- 
ment of the interfaces to neighboring projects, the community of users, and the client's overall objectives of the project. This emerging perspective of project success involves a broadening of project managers' room for maneuvering and, at the same time, an active involvement and interest of the project sponsor. Success is, then, defined and jointly accomplished in partnership with the sponsor (Turner \& Müller, 2003).

\section{Implications for Research and Practice}

Our reflections on the past and maturing understanding of project success lead us to share some thoughts on how these concepts relate to practice and research. Projects are about managing expectations, and expectations have to do with perceptions on success. As this paper has indicated, project success is a complex and ambiguous concept and it changes over the project and product life cycle.

Project managers may find that they are more effective at managing projects when they:

- Think about CSFs at the project onset and consider using the categories within a specific CSF framework to guide the development of appropriate indicators to use for various project and product phases.

- Develop a list of key project stakeholders at the beginning of the project and determine which success category each stakeholder fits into.

- Avoid using single-point indicators of project success and ensure that their project success indicators include both efficiency and effectiveness measures over the span of the project/product life cycle and that there are CSFs that address all key stakeholder needs and wants. This is not to say that all stakeholder wants will be addressed over the course of the project, but it certainly helps to discuss them and place appropriate boundaries on what is reasonably manageable on the project.

- Remain mindful that success measures change over the project and product life cycle and that some of the indicators used at the initial project phases may not be the ones assessed at the closeout phase. Regardless, the indictors identified should be assessed/measured using simple and appropriate measures. It is better to use a few measures and measure them well than to have a laundry list and not address them properly.

- Develop and maintain good relationships and effective communications with key stakeholders, and, in particular, project sponsors because their understanding, involvement, commitment, and appropriate decisions for the project will be essential to achieve project success.

The literature on project CSFs continues to evolve as more holistic frameworks emerge. Several useful models exist and some are being tested empirically. In particular, contributions by Shenhar are pivotal because they address the concept of project success in an integrated manner, and Shenhar's work on project typologies lends itself to further conceptual and empirical studies on project success.

In addition, project management maturity models examine the documented and codified practices within the discipline and focus on tangible assets (Pennypacker, 2001). We are seeing that the return on investment is difficult to capture from such approaches, and this is leading us to focus more on the value of intangible assets within project management (Jugdev, 2003). PMI's support for research into the connections between project management and strategy will continue to place attention on the value of the discipline and allow us to move that value into the senior management realm of attention (Project Management Institute, 2004b).

Our contributions in this paper are threefold. First, we wanted to present a consolidated synthesis of key publications on the success literature to depict how our views on the concept have evolved. Second, project managers are constantly trying to define and manage project success in both subjective and objective ways. A basic understanding of the concepts and the issues related to success is, therefore, essential for proj- ect managers and we hope that we have helped to clarify this understanding. Third, as more people work in an environment where program and portfolio management practices are used, they need to understand how project success is defined, particularly in terms of the project and product life cycles, because program and portfolio success is an aggregate of project success (Blomquist \& Müller, 2005).

Over the past 40 years, we have made considerable progress regarding our evolving understanding of project success. Increasingly, we are beginning to see that holistic project success frameworks are being used in practice. As we journey into the 21 st century, we look forward to project management being supported and invested in as an asset with increasing strategic relevance.

\section{References}

Allee, V. (2001, January 21). Understanding value networks. Retrieved November 20, 2002, from http://www.vernaallee.com/library $\% 20$ articles/Understanding\%20Value $\% 20$ Networks.html

Atkinson, R. (1999). Project management: Cost, time, and quality, two best guesses and a phenomenon, its time to accept other success criteria. International Journal of Project Management, 17(6), 337-342.

Baccarini, D. (1999). The logical framework method for defining project success. Project Management Journal, 30(4), 25-32.

Barney, J. B. (1996). What is performance? In M. D. McEwing (Ed.), Gaining and sustaining competitive advantage (1st ed., pp. 30-64). Reading, MA: Addison-Wesley Publishing Company.

Barney, J. B. (2001). Is the resourcebased "view" a useful perspective for strategic management research? Yes. Academy of Management Review, 26(1), 41-56.

Barney, J. B. (2002). Gaining and sustaining competitive advantage (2nd ed.). Upper Saddle River, NJ: PrenticeHall, Inc.

Baxter, W. T. (1985). Inflation Accounting. Amherst, NY: Prometheus Books. 
Belassi, W., \& Tukel, O. I. (1996). A new framework for determining critical success/failure factors in projects. International Journal of Project Management, 14(3), 141-152.

Belout, A. (1998). Effects of human resource management on project effectiveness and success: Toward a new conceptual framework. International Journal of Project Management, 16(1), 21-26.

Blomquist, T., \& Müller, R. (2005). Roles and Responsibilities of Program and Portfolio Managers. In D. P. Slevin, D. I. Cleland, \& J. K. Pinto (Eds.), Innovations: Project management research 2005 (Vol. 1). Newtown Square, PA: Project Management Institute.

Bounds, G. (1998). The last word on project management. Institute of Industrial Engineers Solutions, 30(11), 41-43.

Brush, C. G., Greene, P. G., Hart, M. M., \& Haller, H. S. (2001). From initial idea to unique advantage: The entrepreneurial challenge of constructing a resource base. The Academy of Management Executive, 15(1), 64-78.

Cabanis, J. (1998). Show me the money: A panel of experts dissects popular notions of measuring project management maturity. PM Network, 12(9), 53-60.

Clarke, A. (1999). A practical use of key success factors to improve the effectiveness of project management. International Journal of Project Management, 17(3), 139-145.

Cleland, D. I., \& Ireland, L. (2002). Project management: Strategic design and implementation (4th ed., Vol. 1). New York: McGraw-Hill.

Cooke-Davies, T. (1990). Return of the project managers. Management Today, Business Information Management (BIM UK) (May), 119-121.

Cooke-Davies, T. (2002). The "real" success factors in projects. International Journal of Project Management, 20(3), 185-190.

De Wit, A. (1988). Measurement of project success. International Journal of Project Management, 6(3), 164-170.

Dinsmore, P. C. (1998). How grown-up is your organization? $P M$ Network, 12(6), 24-26.
Engwall, M. (2002). The futile dream of the perfect goal. In K. SahlinAndersson \& A. Söderholm (Eds.), Beyond project management (Vol. 1, pp. 261-277). Copenhagen, Denmark: Liber-Abstrakt.

ESI-International.

(2001,

November 22). ESI-International. Retrieved November 20, 2002, from http://www.esi-intl.com/

Floyd, S. W., \& Woolridge, B. (1997). Middle management's strategic influence and organizational performance. The Journal of Management Studies, 34(3), 465-485.

Frame, D. J. (1994). The new project management: Tools for an age of rapid change, corporate reengineering, and other business realities (1st ed., Vol. 1). San Francisco: Jossey-Bass Publishers.

Freeman, M., \& Beale, P. (1992). Measuring project success. Project Management Journal, 23(1), 8-18.

Hartman, F. T. (2000). Don't park your brain outside: A practical guide to improving shareholder value with SMART project management (1st ed.). Upper Darby, PA: Project Management Institute.

Ibbs, C. W., \& Kwak, Y. H. (1997). Measuring project management's return on investment. PM Network, 11(11), 36-38.

Jonker, J. (2000). Organizations as responsible contributors to society: Linking quality, sustainability and accountability. Total Quality Management, 11(4-6), S741-S748.

Jugdev, K. (2003). Developing and sustaining project management as a strategic asset: A multiple case study using the resource-based view. Unpublished doctoral dissertation, University of Calgary, Alberta, Canada.

Jugdev, K., \& Thomas, J. (2002a, July 14-17). Blueprint for value creation: Developing and sustaining a project management competitive advantage through the Resource Based View. Paper presented at the 2nd Project Management Institute Conference: Frontiers of Project Management Research and Application, Seattle, WA.

Jugdev, K., \& Thomas, J. (2002b). Project management maturity models: The silver bullets of competitive advantage. Project Management Journal, 33(4), 4-14.
Kerzner, H. (1987). In search of excellence in project management. Journal of Systems Management, 38(2), 30-40.

Kerzner, H. (1994). The growth of modern project management. Project Management Journal, 25(2), 6-9.

Kloppenborg, T., \& Opfer, W. (2002). The current state of project management research: Trends, interpretations, and predictions. Project Management Journal, 33(2), 5-18.

Kujala, J., \& Artto, K. (2000). Criteria for project performance in business context. Project Management, 6(7), 46-53.

Kumar, C. C. P., \& Wolf, C. (1992). Assessing project quality. American Association of Cost Engineers Transactions, 2(40), 40-46.

Lester, D. H. (1998). Critical success factors for new product development. Research Technology Management, 41(1), 36-43.

Lim, C. S., \& Mohamed, M. Z. (1999). Criteria of project success: An exploratory re-examination. International Journal of Project Management, 17(4), 243-248.

Lubianiker, S., \& Schwartz, M (2001, December 1). Enterprise improvement platform (EIP1). Retrieved November 20, 2002, from http://www.lsmzone.com/Default.htm

McManus, K. (1999). Is quality dead? Institute of Industrial Engineers Solutions, 31(7), 32-35.

Might, R. J., \& Fischer, W. A. (1985). The role of structural factors in determining project management success. IEEE Transactions on Engineering Management, EM32(2), 71-78.

Morris, P. W. G., \& Hough, G., H. (1987). The anatomy of major projects: $A$ study of the reality of project management (Vol. 1). Chichester, UK: John Wiley \& Sons, Ltd.

Müller, R. (2003). Communication of IT project sponsors and managers in buyer-seller relationships. Unpublished DBA, Henley Management College, Henley-on-Thames, UK.

Munns, A. K., \& Bjeirmi, B. F. (1996). The role of project management in achieving project success. International Journal of Project Management, 14(2), 81-88. 
Pennypacker, J. (2001). Project management maturity benchmark: A Center for Business Practices (CBP) research report. Havertown, PA: Project Management Solutions, Inc.

Pinto, J. K, \& Covin, J. G. (1989). Critical factors in project implementation: A comparison study of construction and $R \& D$ projects. Technouation, 9(1), 49-51.

Pinto, J. K., \& Mantel, S. J. J. (1990). The causes of project failure. IEEE Transactions on Engineering Management, 37(4), 269-277.

Pinto, J. K., \& Prescott, J. E. (1990). Planning and tactical factors in project implementation success. The Journal of Management Studies, 27(3), 305-328.

Pinto, J. K, \& Slevin, D. P. (1987). Critical factors in successful project implementation. IEEE Transactions on Engineering Management, EM34(1), 22-28.

Pinto, J. K., \& Slevin, D. P. (1988a). Critical success factors across the project life cycle. Project Management Joumal, 19(3), 67-75.

Pinto, J. K., \& Slevin, D. P. (1988b). Project success: Definitions and measurement techniques. Project Management Joumal, 19(1), 67-73.

Pinto, J. K., \& Slevin, D. P. (1989). Critical success factors in $R \& D$ projects. Research Technology Management, 32(1), 31-36.

Project Management Institute. (2000). A guide to the project management body of knowledge (PMBOK ${ }^{\circledR}$ Guide) (2000 ed.). Newtown Square, PA: Author.
Project Management Institute (2004a). A guide to the project management body of knowledge (PMBOK® Guide) (3rd ed.). Newtown Square, PA: Author.

Project Management Institute (2004b, February 10). Project Management Institute Web site. Retrieved February 18, 2004, from http://www.pmi.org/prod/groups/pub lic/documents/info/pp_sponsoredreports.asp

Rumelt, R. P., Schendel, D. E., \& Teece, D. J. (1994). Fundamental issues in strategy. In R. P. Rumelt, D. E. Schendel \& D. J. Teece (Eds.), Fundamental issues in strategy (pp. 947). Cambridge, MA: Harvard Business School Press.

Sahlin, I. (1996). Vad är ett projekt? In I. Sahlin (Ed.), Studentlitteratur (Vol. 1, pp. 238-264). Lund, Sweden.

Shenhar, A. J., Levy, O., \& Dvir, D. (1997). Mapping the dimensions of project success. Project Management Journal, 28(2), 5-13.

Simons, G. R., \& Lucarelli, C. M. (1998). Work breakdown structures. In J. K. Pinto (Ed.), Project Management Handbook (Vol. 1, pp. 159-176). San Francisco: Jossey-Bass.

Standish Group. (2003, Dec 5). The CHAOS chronicles. Retrieved May 8 , 2004, from http://www.standishgroup.com/chaos/introduction.pdf

Sveiby, K.-E. (1997). The new organizational wealth: Managing and measuring knowledge-based assets. San Francisco: Berrett-Koehler.
Toney, F. (1997). What the Fortune 500 know about project management best practices. PM Network, $11(2), 30-34$.

Tukel, O. I., \& Rom, W. O. (2001). An empirical investigation of project evaluation criteria. International Journal of Operations \& Production, 21(3), 400-413.

Turner, J. R. (1999). The handbook of project-based management: Improving the processes for achieving strategic objectives (2nd ed., Vol. 1). London: McGraw-Hill Publishing Co.

Turner, J. R. (2004). Five conditions for project success. International Journal of Project Management, 22(5), 349-350.

Turner, J. R., \& Müller, R. (2003). On the nature of the project as a temporary organization. International Joumal of Project Management, 21(1), 1-8.

Turner, J. R., \& Müller, R. (2004). Communication and co-operation on projects between the project owner as principal and the project manager as agent. European Management Joumal, 22(3), 327-336.

Ulri, B., \& Ulri, D. (2000). Project management in North America: Stability of the concepts. Project Management Joumal, 31(3), 33-43.

Wateridge, J. (1998). How can IS/IT projects be measured for success? International Journal of Project Management, 16(1), 59-63.

Wenell, T. (2000). Wenell om projekt. Uppsala, Sweden: Konsultförlaget.
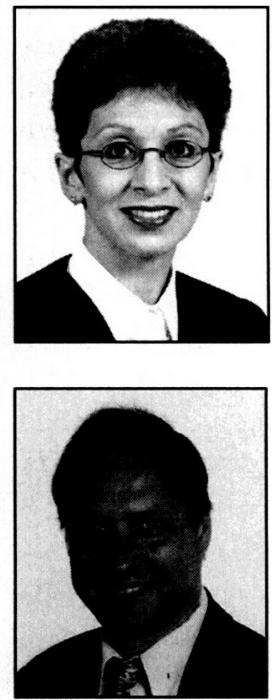

DR. KAM JUGDEV is an Assistant Professor of Project Management and Strategy in the MBA program at Athabasca University in Alberta, Canada and an Adjunct Professor in the Department of Civil Engineering, Schulich School of Engineering, University of Calgary. Her current areas of research include project management as a source of competitive advantage and the Resource-Based View of the Firm as it applies to project management. Dr. Jugdev's work has been published in PM Network, Project Management Journal, and the Journal of International Project Management. She is a reviewer for the International Project Management Journal, IEEE Transactions of Engineering Management, and Academy of Management's Management Education Division conference.

As a member of the Project Management Institute, Academy of Management, Strategic Management Society, Administrative Sciences Association of Canada, and the Western Academy of Management, Dr. Jugdev actively contributes to the advancement of academic and professional communities of management practice across Canada and throughout the world. Readers interested in following up with Dr. Jugdev can reach her at kamj@athabascau.ca

DR. RALF MUUER is Assistant Professor at Umeå University in Sweden and visiting lecturer at NIMBAS University in The Netherlands. He lectures in project management, governance of project-based organizations, and research design and methodology. Dr. Müller's current research focus is on program and portfolio management, and the interactive effects of project managers' leadership style with project type on project success. Dr. Müller's past research was published in European Management Journal, International Journal of Project Management, and Project Management Journal. The majority of his 30 years in business were spent consulting for large enterprises in project management and governance (e.g., as worldwide Director of Project Management in NCR Teradata).

Dr. Müller is a reviewer for the International Journal of Project Management, author of two books and a number of articles in international project management journals, as well as a frequent speaker at researcher and practitioner conferences. He is a co-founder of two PMI chapters in Europe and contributor to the following PMI standards: Organizational Project Management Maturity Model $\left(\mathrm{OPM} 3^{\circ}\right)$, Standard For Program Management, and Standard For Portfolio Management. He can be reached at ralf.mueller@fek.umu.se 